\title{
ENTERPRISE MANAGEMENT AND REGULATION OF ECONOMIC ACTIVITY: THE CASE OF INSURANCE
}

\author{
Jan MONKIEWICZ \\ Faculty of Management \\ Warsaw University of Technology, 02-524 Warszawa, Poland \\ email: J.Monkiewicz@wz.pw.edu.pl
}

\begin{abstract}
Modern enterprise is functioning in a market space in which it is subjected to the whole network of intervention tools in the form of economic regulations. These regulations limit the freedom of its economic activities impacting the business models in use, its internal organization, management systems and, last but not least, its market value. Degree and strength of regulatory intervention is highly differentiated in various countries, depending on the cultivated social and economic model. It also varies depending on the area of economic activities in different groups of enterprises, according to the current perception of its systemic significance. Especially strong regulatory interventions are currently applied for financial institutions.It is because they are threatening the existence of the whole system via the systemic risk they are able to generate.The article explores principal challenges and issues facing the insurance operations and relates them to the enterprise management.
\end{abstract}

Key words: regulation, supervision, quality of regulation, costs of regulation, intervention powers.

1

\section{Introduction}

Modern enterprise is functioning in a market space in which it is subjected to the whole network of intervention tools in the form of economic regulations. These regulations limit the freedom of its economic activities impacting the business models in use, its internal organization, management systems and, last but not least, its market value. Degree and strength of regulatory intervention is highly differentiated in various countries, depending on the cultivated social and economic model. It also varies depending on the area of economic activities in different groups of enterprises, according to the current perception of its systemic significance. Especially strong regulatory interventions are currently applied for financial institutions. This takes foremostly place due to the fact of recognizing their activities as systemic significant.Additionally it is also a result of their business model based on wide utilization ${ }^{1}$ In the social understanding it is a form of intervention into the shape of relations that take place between different subjects. It determines the type of activities and behavior of these subjects through the modification of existing spontaneous patterns.

Regulations can be obligatory, their source is the public authority, or voluntary, their source is the initiative of interested subjects. In such case one speaks of selfregulation or auto-regulation.

\footnotetext{
${ }^{1}$ Surdej A. - Determinanty regulacji administracyjno-prawnych w oddziaływaniu państwa na gospodarkę, Published by AE Kraków, Kraków 2006, p. 9.
}

of debt. resources (trust property) for financing of their transactions. Progressing economic globalization leads at the same time to a situation in which more regulation is accompanied by globalization of applied regulatory solutions. Therefore it leads to inter alia increased regulatory risk due to the replacement of diverse norms and standards with uniform solutions.

This article focuses on the analysis of the sources of current regulatory explosion with relation to the insurance markets, highlights basic regulatory areas, discuss main regulatory challenges and finally provides some thoughts on the issue of cost of maintenance of existing regulatory regimes.

\section{Definitions}

Regulation (lat. regulatio) is defined as arrangement through submission to norms, rules and regulations.

Modern social and economic systems tend to increase the use of different regulatory instruments as well as to replace the voluntary regulations with obligatory regulations. This contributes to the increase of the legislative role of the state. One of the important premises of this phenomenon in the global approach is the observed economic activity and social security privatization process. ${ }^{2}$

\footnotetext{
${ }^{2}$ Gilardi F., Jordana J, Levi - Faur D. - Regulation in the age of globalization: the diffusion of regulatory agencies across Europe and Latin America, Institut Barcelona d'Estudis Internacionals, 1/2006, p. 4.
} 
Contrary to the popular belief it does not lead to deregulation and higher market freedom but to the creation of numerous regulations and supervisory and regulatory institutions. The number of regulatory agencies that operate in the seven economic areas in EU and Latin America(telecommunication, energy, market competition, capital market, food industry, pharmaceutics and natural environment) increased fifteen fold, in 1960 2000 , from 10 to 150 . The most rapid acceleration of the creation of these institutions took place in the last decade of the XXth century, when the number of institutions tripled.

Process of regulatory explosion is accompanied by the increasing technocratization, which is based on the delegation of regulatory authorities from politicians and government structures to regulatory agencies and technocartes. $^{3}$

Both of these phenomena can be explained through the relation of national economic and social activity privatization with the increasing dependence of the state on private capital. It triggers the need to create stable institutional structure, with more expert than political structure, for them.

Another cause can be the progressing regional integration processes, in which regulations and regulatory agencies are the part of the integration process.

For example, European Union created, as part of the commitology system, over 300 various committees (advisory, managing and regulatory) that have essential impact on the legal and economic order of the community. ${ }^{4}$

Another explanation is the globalization of the regulatory standards as a result of economic globalization and the trans-boundary imitation effect.

Regulations consist of sets of standards of different kinds (legal, economical, market related) as well as the rules of their introduction (regulation process). They determine, together with regulatory institutions, the regulatory order in given jurisdiction. Standard is understood as a set of requirements that deal with certain area. It is a kind of "regulatory atom .

Between the listed elements of the regulatory order there exist mutual linkages. For example the content

\footnotetext{
${ }^{3}$ Gilardi T, Jordana J, Levi - Faur D. - Regulation op. cit p. 3.

${ }^{4}$ Commitology determines the European Commission cooperation system with special committees that consist of representatives of particular EU countries. Its main goal is to assure national control over the work of the Commission.
}

and form of accepted standards is dependent both on the regulation process itself and the character of the regulatory institution. Regulation process influences not only the content of the standards, but also the regulatory institutions themselves, which need to adjust to its requirements. On the other hand, these institutions influence the organization of the regulation process.

Table 1. Total number of committees present in the EU commitology system in 2004 and 2005

(source: Report from the Commission on the working of committees during 2005, COM/2006/0446 final)

\begin{tabular}{|c|c|c|}
\hline Political sector/symbol & 2004 & 2005 \\
\hline Enterprise (ENTR) & 29 & 32 \\
\hline Employment (EMPL) & 6 & 6 \\
\hline Agriculture (AGRI) & 30 & 31 \\
\hline Energy and Transport (TREN) & 39 & 38 \\
\hline Environment (ENV) & 35 & 32 \\
\hline $\begin{array}{l}\text { Research and Technological Deve- } \\
\text { lopment (RTD) }\end{array}$ & 3 & 3 \\
\hline Informational Society (INFSO) & 9 & 10 \\
\hline Fisheries and Maritime (FISH) & 3 & 3 \\
\hline Internal Market (MARKT) & 11 & 10 \\
\hline Regional Policy (REGIO) & 2 & 2 \\
\hline Taxation and Customs (TAXUD) & 10 & 10 \\
\hline Education and Culture (EAC) & 9 & 7 \\
\hline $\begin{array}{l}\text { Health and Consumer Protection } \\
\text { (SANCO) }\end{array}$ & 13 & 15 \\
\hline Justice and Home Affairs (JLS) & 10 & 13 \\
\hline External Relations (RELEX) & 3 & 3 \\
\hline Trade (TRADE) & 11 & 12 \\
\hline Enlargement (ELARG) & 2 & 3 \\
\hline External Aid (AIDCO) & 9 & 8 \\
\hline Humanitarian Aid (ECHO) & 1 & 1 \\
\hline Statistics (ESTAT) & 7 & 8 \\
\hline Budget (BUDG) & 2 & 2 \\
\hline Anti-Fraud Office (OLAF) & 1 & 1 \\
\hline TOTAL & 245 & 250 \\
\hline
\end{tabular}




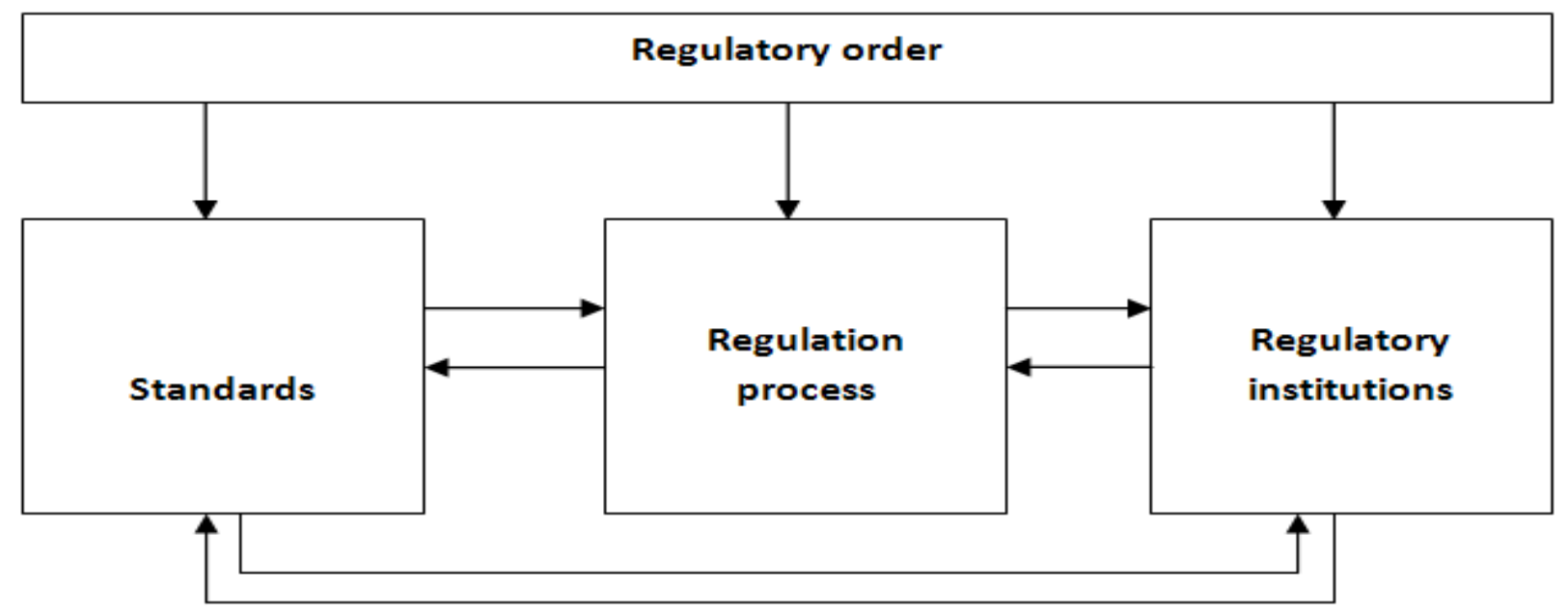

Figure.1 Elements of the regulatory order (source: self elaboration)

Regulations co-exist with the activity of market mechanisms. In many cases regulations replace market standards and mechanisms. In other cases, quite contrary, regulations create market that could not have emerged in any other way (e.g. through introduction of the obligation to acquire certain qualifications, determination to compliance to perform certain roles, necessity to acquire certain equipment etc.).

\section{Basic theories of economic regulation}

The basic premise of the regulation in the market economy is the existence of many flaws and imperfections that lead to market failures.

List of such imperfections includes especially: ${ }^{5}$

- existence of monopoly, which limit the existence of competition and damage the market balance. This can lead to limitation of supply, product scope and inflated prices of products that leads to the transfer of income from non-monopolized areas and consumers to the monopolists,

- existence of externalities, which means that the actual manufacturing cost is lowered through moving it out of the scope of the manufacturer, e.g. through disposing of waste into natural environment, what causes lowering of the manufacturing price and excessive consumption, thus deforming the market,

- existence of information asymmetry, which means different level of access to information of different

\footnotetext{
${ }^{5}$ Nieborak T. - Aspekty prawne funkcjonowania rynku finansowego Unii Europejskiej, Difin, Warszawa 2008, pp. 26 - 27.
}

participants of market transaction, what leads to the contract unbalance. It damages the mechanisms of effective market mechanisms,

- lack of service availability, meaning the necessity to assure supply of particular services even if it is not cost-effective for the manufacturer but is profitable for the consumers (e.g. transportation to destinations difficult to reach or at certain hours with lowered demand for this service),

- unfair business practices, which can occur due to usage of the dominant market position or use of illegal activities,

- inequality of legal relation participants, due to the economic potential inequality of the subjects that leads to the temptation of abuse from the stronger subject to gain unjustified profits,

- necessity to coordinate activities to reach certain goals in situation when individual subjects are unable to reach them. It includes e.g. creation of technical operation infrastructure such as databases, networks etc., technical standards, educational devices etc.

Market failures became the basis for the formulation of the basic theoretical construction to justify the use of economic regulation - the public interest theory. ${ }^{6}$ According to the theory, regulation should be perceived as a strive to accomplish social interests and the regula-

\footnotetext{
${ }^{6}$ Hantke - Domas M - The public interest theory of regulation: non-existence or misinterpretation, European Journal of Law and Economics, No. 15, 2003, pp. 165-195; Goran P., Hagy T. Theories on the economics of regulation. A survey of the literature from European perspective, European Journal of Law and Economics, No. 4, 1997, pp. $337-370$.
} 
tory activity as aimed at their achievement. The theory assumes that the regulator will be neutral in the realization of the public interest and that it is able to neutrally determine it. According to the theory regulation enables the realization of the three following goals:

- protection of strategic interests of the society,

- effective allocation of resources,

- increase of the market mechanisms effectiveness.

This theory is criticized by the proponents of the economic regulation theory, which claims that most of the regulations do not serve public interest but, on the contrary, favor the interests of the groups that are the subject of regulation. This is the result of, so called, regulatory capture, with actual subordination of public interest to private business. ${ }^{7}$ Regulation, instead of being enforced to economical subjects to protect the realization of public interest, becomes a service sought by these subjects that is usually bought by them. As a result, according to the theory, the regulator becomes the prisoner of the regulated subjects.

Main thesis of the school of economic regulation can be summed up as follows:

- regulations are introduced only in the areas where there are considerable benefits that can be overtaken by pressure groups,

- their shape is reflected by the political forces relations between the benefactors that gain from the regulations.

The school of economic theory of regulation in effect underlines the necessity of deregulation of the economy and subjecting it to the mechanisms of the competitive market.

\section{Quality of economic regulations}

Final results of applying regulation depend on the quality of the regulation. Proper regulations can only be created in the conditions of properly organized regulatory process. It is properly organized only if all interested subjects can participate in it and when they can present their statements and arguments as well as formulate proper legislation solutions during the process. Therefore the regulation process cannot be performed in a hurry. It needs to have the necessary time for analysis, evaluation and reflection. At the same time the

\footnotetext{
${ }^{7}$ Economic regulation theory and regulatory capture are mainly associated with an American economist G. Stigler, winner of the Nobel Prize in economics in 1982.
}

regulation process needs to be transparent, so that all of the participants have equal access to the information it produces and are informed about the position of other subjects.

As for the substantial quality of the regulation the following four aspects should be crucial: ${ }^{8}$

- regulatory adequacy - relevance to economic reality. Proper regulation must be based relevant interpretation of reality and deal with its basic aspects,

- regulatory impartiality - a situation when regulations do not create privileged states for any of market subjects, thus assuring free competition in the market,

- regulatory proportionality - a situation when regulatory solutions used are adjusted to the scale of the problem. Therefore such solutions do not lead to excessive interference in the market mechanisms, used business models, customs etc. what at the same time reduces the cost of using them,

- regulatory stability - avoidance of frequent changes in obliging regulations, because it introduces uncertainty of activity conditions for the market subjects and increases the cost of regulation.

The quality of financial sector regulation, including insurance sector is, since 1999, subjected to external evaluation by International Monetary Fund and The World Bank as part of the Financial Sector Assessment Program (FSAP). One of the components of this Program is the Report on the Observance of Standards and Codes (ROSC), in which these institutions perform the evaluation of application of global International Association of Insurance Supervisors standards by the analyzed countries. Such reports are later transferred to national authorities together with recommendations to undertake necessary activities.

\section{Definition and subject of insurance regulation}

Insurance regulations are the collection of standards currently in force for the whole insurance market as well as particular insurance institutions and their relations with the external environment (supervisors, brokers, investors, customers etc.). They determine the minimal requirements towards undertaking that perform or plans to perform insurance activities.

\footnotetext{
${ }^{8}$ Skipper H.D, Klein R.W. - Insurance regulation in the public interest: the path towards solvent, competitive markets, Centre for Risk Management and Insurance Research, Georgia State University, Atlanta, Georgia, August 23, 1999, pp. 23-30.
} 


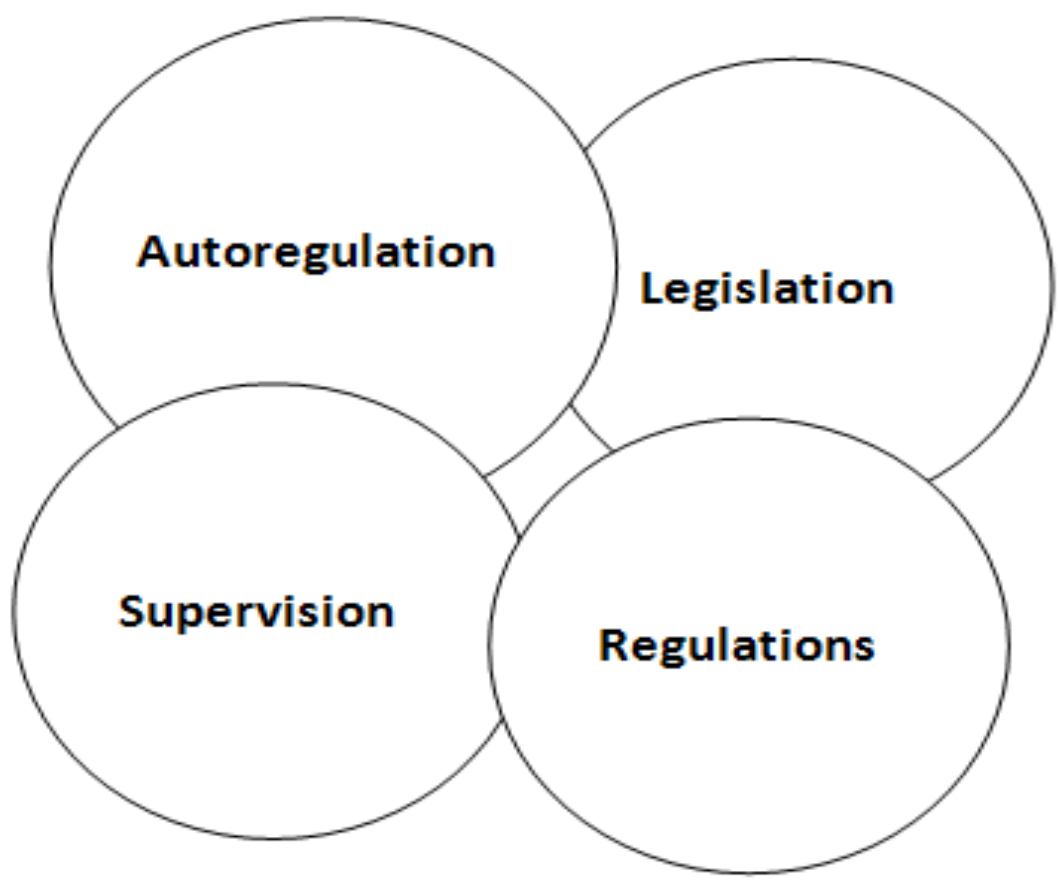

Figure 2. Regulations - basic relations (source: self elaboration)

It takes the form of various legal and administrative acts (e.g. in Poland these are acts, regulations, orders, recommendations, decisions etc.). Therefore, most of them are connected with the legislation activities of the nation. Thus they reflect the legal culture of given country, which directly transfers to its regulatory culture. ${ }^{9}$ One should not identify the insurance regulations strictly with the legislation activities. Creation of regulations is also performed by the insurance supervision institutions, both through formalized decisions and used supervisory practice (so called "soft regulations").

Public and legal regulations can be also supplemented with self-regulatory practices (e.g. best practice code) and customs originating from the insurance environment. They usually have more significant role in mature markets and these markets where liberal economical policy is introduced. Basic relations in this field are presented in the Figure 2. Insurance regulations consist of three basic components: ${ }^{10}$

- regulatory order that determines who performs the regulatory activity, rules of creation, implementation and expiration of regulations (regulation process), subject of regulation and the set of rules, reg-

\footnotetext{
${ }^{9}$ Nieborak T. - Aspekty prawne... op cit, p. 21.

${ }^{10}$ Por Financial sector regulation: issues and gaps, IMF, August 4, 2004, p. 9.
}

ulations, norms and standards in force for the insurance activities,

- supervisory order that determined who supervises the insurance market and institutions as well as describes how is it attached and what competences it has,

- market safety networks that determine scope and market and its participants protection from the insolvency of insurance companies and regulates the compensation connected with results of possible bankruptcy.

These regulations deal with to sets in the subjective approach: on one hand the horizontal relations - mutual authority and obligations of market relations subjects (insurers and insured), regulated with the civil law, and, on the other hand, vertical relations - authority and legal obligations of market relations subjects and the nation, regulated with the public law. In both cases the interference of the nation, which will influence its final state, is possible.

\section{$6 \quad$ Premises and goals of insurance regulation}

Premises of the insurance regulations usage are possible to derivate directly from existing theoretical regulation constructions, especially from the public interest theory. This theory assumes that market mechanisms 
in their pure form lead to reaching a worse social result in comparison with the situation when these mechanisms are corrected through legal and administrative activities of the nation. It focuses mainly in counter activities towards market failures for the following threats:

- systemic risk - risk of economic system collapse due to insurance companies crisis. This can lead to significant negative macroeconomic issues due to the lack of necessary insurance protection or the deficit of trust for insurance companies,

- risk of bankruptcy - meaning cancellation of undertaken insurance contracts, what can result in negative micro-economic consequences for the insured and other creditors (e.g. injured parties),

- risk of calamity - meaning accumulation of considerable insurance pay-offs, what can overwhelm the strengths of the insurance system. The result of such events would be major negative consequences in both micro and macro level.

- asymmetry of information - situation in which the sides of the insurance contract have different information about each other, insurance product and the contract. Leveling of this information base, which sometimes favors the insurers (e.g. the information about market demand) and sometimes favors the insured (e.g. the knowledge about one's risk profile), can be a premise to undertake certain regulation activities.

- moral hazard, temptation of embezzlement, is the reduced caution in the activities of the insured after concluding the insurance contract and their tendency to hide crucial information, which can negatively influence the conditions of the insurance contract, from the insurance company. This can lead to the higher level of loss and reduced reliability of the insurer.

- adverse selection of risk, unfavorable selection of risk due to information asymmetry, what leads to increased risk of insurer's bankruptcy.

Insurance regulations aim to reach certain goals, which, according to modern regulatory tendencies, should be declared publicly to allow the possibility of social supervision over the shape of their regulation and the supervision policy. Usually these goals include market stability (continuity of insurance supply and a certain trust level for the insurance companies), its safety (avoidance of bankruptcy shock through certain activities and creation of market security networks), transparency (open communication with the market and supervisory institutions) and legality also known as integrity (legality of transactions, both in content and form as well as legality of used financial resources).

\section{Basic areas of insurance regulation}

Insurance regulations create rules, regulations, norms and standards that cover many problem areas. Key problem areas are the following:

- start up of insurance activities,

- performance of activities including:

- restructuring activities,

- mergers of enterprises,

- transfer of portfolio,

- termination of activities, declaration of bankruptcy,

- finance management,

- broker activities,

- insurance contracts,

- market supervision.

In case of public regulations they can be collected in a single act of law (e.g. code) or dispersed in few places (what is the most common solution). These regulations can be collected both in the regulations of insurance as well as civic and trade law. For example in Poland we can find it in: civil code, maritime code, trade code, insurance activities act, obligatory insurance act, UFG and PBUK, insurance broker act and insurance and pension supervision act.

\subsection{Licensing}

Insurance companies are treated as part of the financial services market due to the trust nature of its activities. Therefore performance of insurance activities is subjected to licensing (receiving permission). Its aim is to assure that the insurance protection is fit and proper and it favors the stability and credibility of the whole insurance system. Firstly, regulations on performance of the insurance activities include the definition of insurance activity and the insurer.

For example Polish law defines insurance activities as performance of activities connected with offering protection and protecting in case of occurrence of risk of random events. However, insurer is defined as a subject leading such kind of activity, who recieved permission in this scope from proper authorities.

It is necessary to emphasize that proper definition of insurance activities has a major practical relevance. 
It allows determining what kind of activities, based on the insurance regulations, need to be performed and what activities can be performed on the basis of general market regulations. In some cases there are situations when various subjects undertake, warily or unwarily, insurance activities without the licensing procedure (for example medical subscriptions offered in Poland). It allows avoiding the loss of time for adjustment to the licensing requirements and performing activity in, so called, regulation "grey area" with the use of arbitration regulatory. The temptation to use such solutions will be greater when the licensing regulations are more strict and the weaker the law is executed in given jurisdiction.

Licensing is based on the researching of the fulfillment criteria suitability of the regulation permission of the applying subject. Currently mostly the suitability of the investors (shareholders) and legitimacy of the financial resources they acquire.

It is also determined whether the applicants have proper financial resources to perform activity of planned profile and in planned scope. Another crucial criterion of the suitability of the applicant is the proper competence and experience level as well as recognition of his key partners (e.g. members of the board, supervisory board, actuaries, internal auditors). Usually the most serious charge for such persons is a court sentence in force. Important factor of the application is a professional action plan for the time horizon of few years, what allows evaluating the credibility and professionalism of the applicant and allows continuous supervision of its economical situation.

Organizational risk management and proper systems and procedures connected with this area become more and more significant criterion of suitability. It is crucial to emphasize that licensing is performed by the same institutions that later are responsible for the supervision of the insurers. Sometimes this responsibility is divided. Such practice was present in Poland until 2002. Licensing was part of the competence of the Ministry of Finance and the supervision was performed by the National Insurance Supervision Department (PUNU).

Licensing procedures are time and labor consuming. They require gathering and checking much information, what can be extremely complex in the age of globalization, and it is usually necessary to gather data that is stored in a different country. According to the provided information an average time of license decision acquiring around the world takes from 3 to 6 months. ${ }^{11}$ However, in some cases, it takes much more time.

Most countries in the world grant such permissions sine die and they do not have to be renewed, although in specific cases such permission can be cancelled. Sometimes permissions are given for a specific period of time (e.g. in Ukraine).

Majority of countries do not grant permissions for composite insurers, who provide insurance packages for both life and property. This is justified by the possible temptation of using assets from life insurance for the purposes of property insurance.

Granted permissions, by authority of law, can include all groups from given insurance group or relate to each group separately. Current international practice is divided equally in this matter. Polish regulations are compliant with the second solution.

Applying subject, in majority of countries, cannot perform other professional activities than insurance activities. This rule protects the insurance activities from risks that could have been transferred from other areas of activity. However, in some cases there are exceptions from this rule. For example in Poland the insurance companies are allowed to seek, apart from insurance activities, customers for their open pension funds and distribute banking products.

Revoking a license takes place when the insurance company is no longer compliant with the requirements for such activities (e.g. limited capital, unqualified staff, illegal activities etc.) or due to a request of an individual subject, which decided to stop the activity as insurer.

\subsection{Performance of insurance activities}

Modern insurance regulations claim that considerable owners, members of the board and supervisory board, actuaries and auditors need to fulfill the criteria of regulatory suitability. It usually means that they are honest, competent, experienced and qualified.

Putting so much attention to the responsibility of people has its justification in the history of the insurance sector.

Research proves that the basic source of problems in the functioning of the insurers and the main cause

\footnotetext{
${ }^{11}$ Report on laws, regulations and practices in IAIS member jurisdictions, IAIS, December 2007, p. 13.
} 
of their bankruptcy are the incompetent or dishonest owners and/or key workers.

Ownership structure can be changed in the insurance company during its activities. Regulations in most countries require receiving an approval for purchasing the majority of shares or concluding a contract, which indicate that given subject can directly or indirectly take control over the insurer. The control is usually understood as an ownership of particular number of shares or other instrument over the minimal necessary level stated in the regulation, right to vote in this matter and the possibility to change the management of the insurance company.

Performance of insurance activities might require transferring part or whole insurance portfolio (insurance contracts in force) to other subject, which takes over the rights and obligations from concluded contracts. This activity is usually subjected to particular regulation that protects the interests of the insured. The main focus is put on the conditions of the contract that should not be worse than in previous insurer. Most modern economies require an acceptance of supervisory institution for the insurance portfolio transfer, both in the silent form (no objections) or through issuing of permission.

We speak of similar situation in case of a fusion of two or more insurance companies. This fusion leads to a creation of a new subject that becomes a legal successor of merged companies. Such operation is subjected to the permission acquiring from proper competent authorities, which usually include insurance supervision departments and institutions responsible for the protection of the competition.

Insurance company can disturb the obliging rules, what can lead to the implementation of a reparation program towards it. Currently worldwide such programs are undertaken in case of risk of threat to financial stability of the insurer and especially the risk of insolvency. Such situation can be defined as a threat of risk that already happened (e.g. lowering the capital level below the solvency margin), what is currently a dominating standard, or as a threat that can happen in the future, what is based on the use of scenario analysis methods and stress-tests - an important regulatory innovation. At the same time the rule of supervisory intervention ladder is obeyed - reparation regulations allow to escalate undertake activities according to the threat level.

For example, Polish law anticipates three-step reparation ladder, starting from elaboration and presentation of the reparation plan to the supervisory authorities, which needs to include i.e. insurance company financial stability threat elimination activity program. These can result from improper level of own capital, guarantee capital or technical and insurance allowance. Moreover, in serious cases, receiver can be introduced in the company, who should supervise the implementation of the reparation plan. Finally it can be necessary to establish receivership (trust management), which overtakes the authority of the board of directors, supervisory board and the shareholders annual meeting.

The last level of reparation interference is the censure vote for the statute authorities of the insurer and is a sign of lack of trust that these authorities are able to solve issues on their own.

Currently one of the developing subjects of the regulatory penetration is the activity of insurance groups and financial conglomerates. Such regulations are currently applied in half of the countries in the World. ${ }^{12}$

Regulations on insurance groups were firstly introduced in European Union in 1998 through acceptance of the directive about additional supervision over insurance groups (Directive 98/78/EC z 27 October 1998). In most countries these regulation do not require the mother-company to be a licensed financial institution. Nevertheless the suitability requirements need to be fulfilled by this company, it has to own proper internal control system and it needs to provide financial reports on regular basis. Also the possibility of direct control over mother-company and gaining all necessary supervisory information is possible in most cases.

Used regulatory requirements usually deal with the concentration of risk in the group, ownership of internal control system, forbidding of multilevel capital gearing, ownership of sufficient own capital at the group level and the necessity to reveal the internal group transactions.

Organizational and management standards are becoming one of the most important factors of modern insurance companies' activities. This results from a fact that operational risk is recognized as one of the crucial risk factor that threatens the insurance companies. ${ }^{13}$

\footnotetext{
${ }^{12}$ Report on insurance laws, regulations and practices in IAIS member jurisdictions IAIS, September 2008, pp. 11 - 15.

${ }^{13}$ In the most general manner the operational risk is understood as the risk of loss due to faulty control systems, human error or improper - see Kendall R - Zarządzanie ryzykiem dla menadżerów, Liber, Warszawa 2000, p. 163.
} 


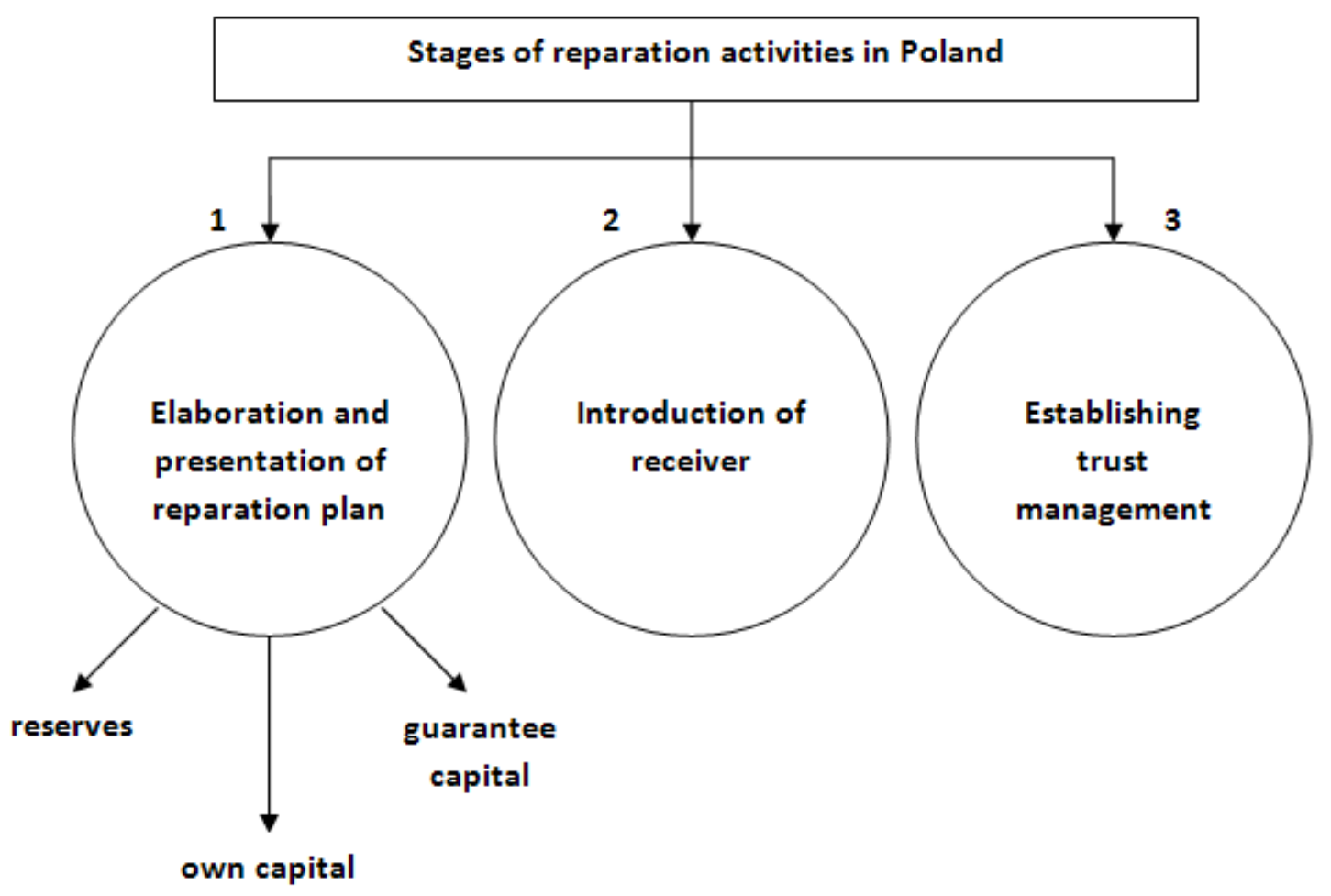

Figure 3. Reparation activity in insurance company (source: self elaboration)

This fact is reflected in the new EU directive on Solvency II, where the operational risk is present as a separate factor of the insurance company risk portfolio alongside insurance, market and loan risk.

Other issues that are in the scope of special interest of regulatory activities is functioning corporate governance in the insurance company with detailed determination of the competences of particular authorities and organizational units as well as properly organized informational and decision-making procedures.

Operational risk management system, which includes insurance (e.g. obligation to perform actuarial audits), financial (market), loan and operational risks, more commonly becomes a distinguished area in the insurance regulations. ${ }^{14}$ One of the significant components of the corporate governance and the risk management system is the internal control. In number of jurisdictions the insurance regulations directly oblige the insurance companies to develop the control functions and organize control authorities. Usually the basic standards of such control, like cross-checking, double asset control or double signature, are determined. One of the

\footnotetext{
${ }^{14}$ Report on insurance laws, regulations and practices in IAIS member jurisdictions, IAIS, September 2007, pp. 7-10.
}

components of the internal control system is the internal and external audit. Rules of functioning and application are usually subjected to regulation. For example, the regulation obliging the insurers to use the external audit for the evaluation of the financial reports, periodical rotation of external auditors or the independence rule of the internal auditors is commonly used.

Modern insurance regulations also include general norms of insurance broker activity, what is connected with the fact that major part of sold insurances is not performed directly by the insurers but with the help of insurance brokers. ${ }^{15}$

Usually such regulations introduce the division of brokers into two categories: agents (subjects that operate in the name of the insurer and independent brokers. Usually the criterion for the latter is lack of contract obligation, lack of constant salary and dispersion of their business portfolio among many different insurers. In most countries the number of agents is much higher than the number of independent brokers. Insurance broker regulations usually deal with qualification requirements (education, professional experience,

\footnotetext{
${ }^{15}$ Insurance laws regulations and practices in IAIS member jurisdictions, IAIS, December 2007, p. 48.
} 
minimal age, sterling reputation etc.) and the rules of performance of their work.

\subsection{Termination of business activities}

Termination of business activities by an insurance company is currently the standard subject of insurance regulation. Their superior goal is to assure orderly withdrawal of the insurer form the insurance market without negative influence on the interests of the insured. Surcease of activity in the formal and legal aspect is connected with the liquidation of the insurer, either voluntary (by the interested party) or compulsory (due to an administrative decision). In both cases insurance regulations award such competences to the supervisory authorities.

Voluntary liquidation is a result of a business decision of the insurer. Compulsory liquidation is a result of a permanent loss of the insurer of the ability to perform insurance activities as well as insolvency and threat of bankruptcy, connected with it.

It is important to emphasize that the issues of the insurer bankruptcy are, in most countries in the world, subject to separate legal regulations. It is connected with the separation of the nature of insurance business activities and its insurance business model from other types of business activities.

Bankruptcy regulations generally relate to three main issues: premises to start the bankruptcy procedure, subjects authorized to initiate bankruptcy procedure and participation in the procedure and protection of the interest of the insured.

Modern regulation causes of the bankruptcy procedures are connected with the lack of sufficient assets to cover the debit side (liabilities are greater than the assets), insolvency (when debtor is not able to regulate his current liabilities) or the need to protect public interest. Sometimes these are cumulative ant sometimes alternative criteria. ${ }^{16}$

In current regulatory reality the authority to initiate bankruptcy procedure is usually granted to supervisory authorities, even though in many jurisdictions such possibility is granted to the boards of insurance companies and their creditors. ${ }^{17}$

\footnotetext{
${ }^{16}$ Report on insurance laws, regulations and practices in IAIS member jurisdictions, IAIS, October 2005, p. 49.

${ }^{17}$ Ibid p. 49.
}

If it comes to the protection of the interest of the insured, insurance regulations relate to the issues by:

- granting high priority to insurance liabilities in the total list of liabilities, especially with relation to the assets that cover the insurance reserves,

- introduction of guaranteed compensation system for the customers of insurers that have bankrupted,

- including the insured representative to the supervision and modeling of the bankruptcy process.

\subsection{Financial regulations for the insurers}

The key area of insurance regulations is the finance economy of the insurance companies, especially in the scope of assurance of solvency during the period of its functioning (see Fig. 6 for details). These regulations relate both to assets and liabilities.

The subjects of modern regulations at the side of assets are usually:

- rules to determine the value of assets for the regulatory needs (present value, historical, allowable components etc.),

- determination of allowable investment instruments, including the concentration limits (e.g. in one instrument or one subject),

- determination of used investment rules (e.g. the prudent man rule).

The subjects of modern regulations at the side of liabilities are usually:

- ways to determine the value of insurance liabilities,

- rules to create reserves for liabilities,

- rules to determine the risk margin for liability value,

- rules to determine the level of own capital for regulatory needs,

- determination of allowable forms of own capital

In most insurance jurisdictions there are detailed requirements towards the level of solvency margin, calculated according to established formulas, usually with relation to the value of the insurance contribution, type of undertaken activities (structure of insurance portfolio), company assets, company liabilities and type of reinsurance agreements.

Insurer risk exposition and quality of his management systems becomes more and more significant among used solvency models. It is a main point in a recently acclaimed UE solvency directive (Solvency II). 
Insurance regulations used in particular jurisdictions can differ from one to another in many aspects. Particularly the differences can involve the level of detail, scope, role granted to given market discipline and finally the position and type of supervision.

In case of the level of detail, modern regulation systems can be divided into ones based on detailed rules and ones on accepted regulations. In first case we speak of determined standards that precisely describe current requirements (e.g. financial, organizational, legal etc.). In the second case norms are of general character and focus on the desired outcomes and not on the detailed way of gaining them. For example, instead of providing detailed information about the product character for customers, they can include a norm stating that the customer needs to be informed by the insurer in a manner that allows him or her to make reasonable choice of the product. Such regulations are more difficult to use because of the possible differences in the evaluation of its perception. That is why they are developed in mature markets with proper law culture. Their main advantage is the possibility to regulate the subject to select the best realization for the obliging requirements.

Modern regulatory systems focus on the insurance authorities in case of the regulation subjects. They assume that the quality of these authorities decides about proper functioning of insurance markets.

The key issue, in this aspect, is the question of understanding these institutions. Is it going to based on the formal and legal logic, which indicates that rge regulation subjects should be legal subjects - registered insurance companies, or the economical logic, which perceives the subject of regulation as economical subjects, enterprise groups, leading coordinated insurance activities (the insurance groups).

There is a possibility to use different perspective on this issue and focus of the regulatory scope on offered products (e.g. rules of creation and construction, rates, risk division etc.) and / or the functioning of the market (e.g. product distribution, outsourcing rules, creation and construction of insurance databases, market concentration rules, market accessibility rules etc.).

Role of granting market discipline, groups of institutions and market influence instruments that impact the behavior of insurance authorities, is becoming one of the most important problems of modern regulatory systems. It includes opinions and decisions undertaken by investors (shareholders), creditors, including customers, external auditors, evaluation institutions (e.g. rating agencies) etc.

Its use allows strengthening the administrative and legal influence and decreasing the necessary supervisory effort. Many different customer organizations and professional societies, which influence the behavior of the insurer, should be counted into this group. This discipline functions better at mature and competitive markets.

Market discipline can considerably support the functioning of insurance supervision.

\section{Modern regulatory challenges}

Insurance regulations have to follow the changes that take place in the character and style of performance of the insurance activities as well as in institutional conditionings of the national regulatory freedom.

From this perspective the key issues are globalization, increasing dependence of insurances from other segments of the financial market and sampling of turnover. In present conditions globalization should be deliberated in terms of threats (e.g. climate changes, pandemics, global financial shocks), markets (increasing importance of transboundary operations), customers (increasing importance of international insurance programs), operators (increasing value of international insurance companies) and the increasing globalization of regulatory standards (Fig. 4).

Modern insurance regulatory standards are more commonly created in global institutions at transnational level. Special role in this scope is played by International Association of Insurance Supervisors (IAIS).

It was created in 1994 and currently it combines 140 insurance jurisdictions, being the general law-making institution in the World. These norms are referential to national or regional regulatory systems. Apart form IAIS the activities of Basel Committee (determining reference norms for banking) International Organization of Securities Commissions (determining the regulatory order for the capital market) and International Organization of Pension Supervisors (regulations on employee pension funds) become more and more significant. 


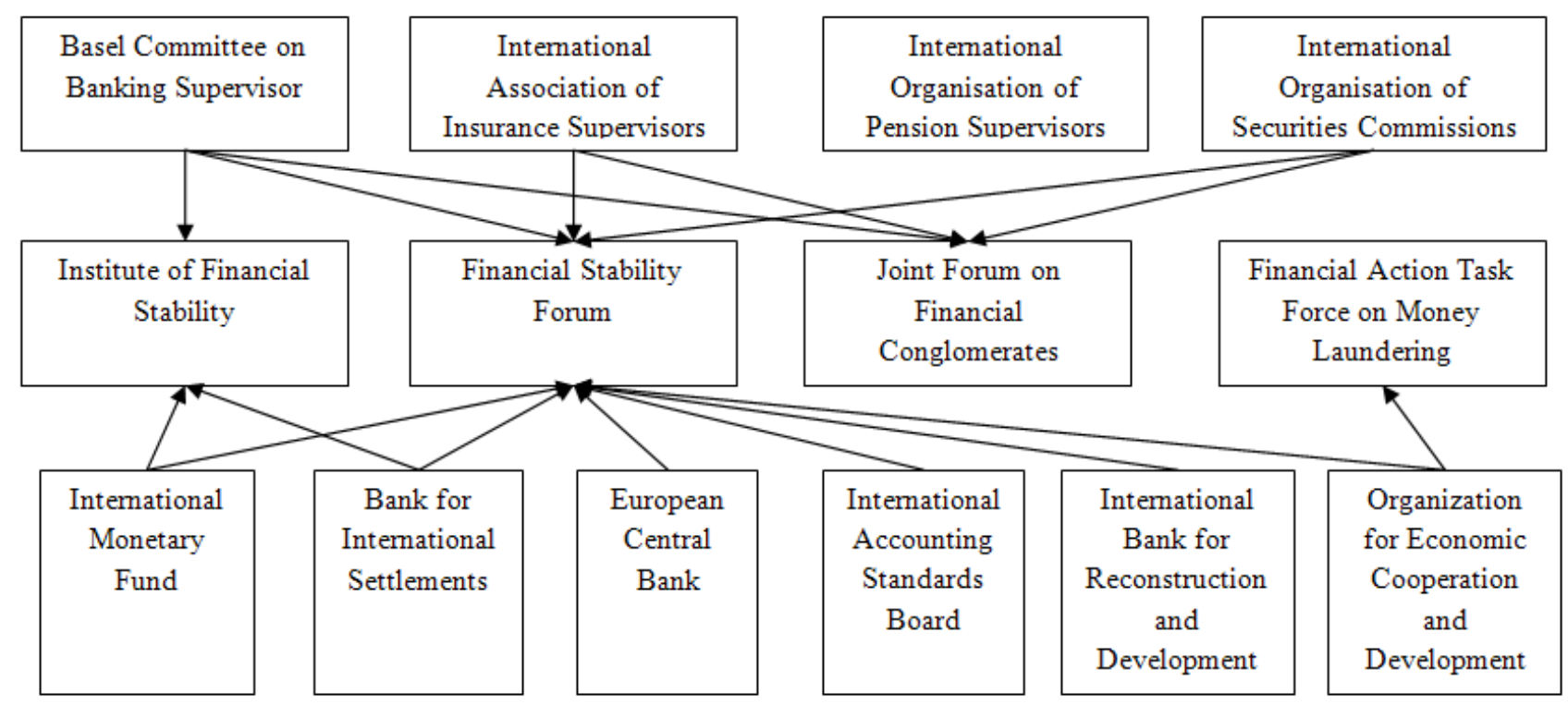

Figure 4. International regulatory structure of financial markets (source: self elaboration)

It is connected with the trans-sector connections of insurance with other areas of financial markets. All of these law-making institutions are in the scope of influence of other institutions, which are engaged in the coordination of their activities on global scale (e.g. Financial Stability Forum or Joint Forum) or implementation strengthening of their recommendations (e.g. IMF, ECB, BIS or the World Bank).

Modern insurances become more strongly connected with the capital market, a.o. through securitization mechanisms and banking (see Fig. 4), becoming part of the regulatory fields of other sectors of financial institutions. Finally, modern regulations must cope with challenges coming from progressing addiction of insurance companies from digitization ov economic turnover.

\section{Cost of regulation}

Regulations do not have a price but they generate cost. It occurs in a number of different places, thus it is difficult even to estimate them. In most general manner these costs can be divided into three basic categories ${ }^{18}$ :

- cost of public regulatory system,

- direct compliance cost of insurance companies,

\footnotetext{
${ }^{18}$ Grace M.F., Klein R.W - Efficiency implications of alternative regulatory structures for insurance, Centre for Risk Management and Insurance Research, Georgia State University, June 10, 1999, pp. 23 - 26.
}

- indirect cost of insurance companies.

The most visible and easiest to determine position are the costs of the public regulatory system.

It includes the cost of supervisory institution maintenance over the activities of insurance subjects together with the cost of fees and taxes. Costs calculated in such manner represented in the USA in 1997 1,3\% of insurance premium of the insurers. ${ }^{19}$

Direct charging of the insurance premium with the cost of supervisory institution maintenance was $0,08 \%$ in the same year so it was a little more than $7 \%$ of fees and taxes paid by insurers to the public sector at that time. At the same time the fees for insurers for that purpose in USA were infavorable in comparison with similar fees for other subjects of the financial sector (see table 3).

This indicates that their competitive position could have deteriorated due to higher cost of supervision.

Second cost position is the spending of insurance companies for the internal adjustment to the regulatory requirements e.g. preparation of proper informational systems for the needs of the supervision, cost of external auditors research, implementation of suitable procedures, responding to inquiries form the supervisory authorities etc.

\footnotetext{
${ }^{19}$ Grace M.F., Klein R.W - op. cit p. 25.
} 
Table 3. Cost of supervisory institution maintenance in USA, 1997

Source: Grace M.F, Klein R.W-Efficiency implications of alternative structures in insurance regulation, Georgia State University, June 10,1999,p.43

\begin{tabular}{|l|c|c|c|c|c|}
\hline \multicolumn{1}{|c|}{ Supervisory institution } & $\begin{array}{c}\text { No of super- } \\
\text { vised subjects }\end{array}$ & $\begin{array}{c}\text { Budget } \\
\text { (in mil. USD) }\end{array}$ & $\begin{array}{c}\text { Assets } \\
\text { (in bil. USD) }\end{array}$ & $\begin{array}{c}\% \\
\text { Assets }\end{array}$ & $\begin{array}{c}\text { Per 1 } \\
\text { subject }\end{array}$ \\
\hline $\begin{array}{l}\text { State Insurance Supervision } \\
\text { and NAIC }\end{array}$ & 7872 & 785,4 & 3,433 & 0,023 & 99,76 \\
\hline Federal Reserve System & 8007 & 517,0 & 4,791 & 0,011 & 64,56 \\
\hline Financial Supervisor Office & 2597 & 350,0 & 2,894 & 0,012 & 134,77 \\
\hline FDIC & 10922 & 605,0 & 5,607 & 0,011 & 55,39 \\
\hline Loan Supervision Office & 1215 & 151,0 & 777,000 & 0,019 & 124,28 \\
\hline $\begin{array}{l}\text { National Credit Union Admin- } \\
\text { istration }\end{array}$ & 11238 & 46,3 & 351,000 & 0,013 & 4,120 \\
\hline
\end{tabular}

These are much more difficult to calculate and analyze. It usually contributes to the majority of cost. For example, there are estimations that show cost of state supervisory system is costing the American insurers approximately 6 billion USD per year - six times grater than the direct cost of maintenance of public supervision. ${ }^{20}$

According to research performed by the University of Zurich, 4,5\% of bank cost in this country is connected with its adjustment to regulatory requirements. What is more, this cost is increasing.

The same research indicates that the number of people employed in the banking institutions regulatory authorities in Switzerland has trilled in recent years. ${ }^{21}$

Finally the third and most important regulation cost position is the indirect cost of insurance companies due to adjustment to regulation requirements e.g. regulatory adjustment of used business models, obliging investment limits or product regulations.

It is important to emphasize that direct and indirect costs of regulation of insurance companies are greater when the changes of used solutions are more frequent. Therefore, the stability of agreed solutions is of crucial importance.

\footnotetext{
${ }^{20}$ Coudrou C.M - The Reed for U.S. insurance regulatory reform: A life insurance perspective, Progres Newsletter, No. 48.

21 Integrated supervision. Lessing or curse? Credit Swiss Worldwide, 17.11.2006, p 1.
}

\section{References}

[1] Avgouleas E. - Financial regulation, behavioural finance and the global credit crisis: in serch of a new regulatory model. Draft, SSRN, 03.09.2008.

[2] Baltensperger E., Buomberger P., Iuppa A.A., Keller B., Wicki A. - Regulation and intervention in the insurance industry - fundamental issues. The Geneva Association, The Geneva Reports, Risk and Insurance Research, No. 1, February 2008.

[3] Cihak M., Podpiera R. - Is one dog better than three? International experience with integrated financial sector supervision. IMF Working Paper, WP 06/57, March 2006.

[4] Cihak M., Tieman A. - Quality of financial sector regulation and supervision around the world. IMF Working Paper WP/08/190, August 2008.

[5] Coudrou C.M - The Reed for U.S. insurance regulatory reform: A life insurance perspective. Progres Newsletter, No. 48, 2005.

[6] De Larosiere J. - The high-level group on financial supervision in the EU. Brussels, 25 February 2009.

[7] Developments in the EU arrangements for financial stability [in] ECB Monthly Bulletin, April 2008, pp. 75-87.

[8] Di Giorgio G., Di Noia C., Piatti L. - Financial Market Regulation: the case of Italy and proposal for the Euro area. Financial Institutions Centre, The Wharton School, University of Pensylvania, June 2000. 
[9] Gilardi F., Jordana J., Levi-Faur D. - Regulation in the age of globalization: the diffusion of regulatory agencies across Europe and Latin America. Institut Barcelona d'Estudos Internacionals 2006.

[10] Goodhart C.A.E. - The regulatory response to the financial crisis [in] CESIFO Working Paper. No. 2257, March 2008.

[11] Goran P., Hagy T. - Theories on the economics of regulation. A survey of the literature from European perspective [in] European Journal of Law and Economics. No. 4, 1997.

[12] Grace M.F., Klein R.W. - Insurance regulation: the need for policy reform. Centre for Management and Insurance Research, Georgia University, Draft, July $5,2008$.

[13] Hantke - Domas M - The public interest theory of regulation: non-existence or misinterpretation [in] European Journal of Law and Economics. No. 15, 2003, pp. 165-195.

[14] Hardy D. C., Nieto M.J. - Cross-border coordination of prudential supervision and deposit guarantees, IMF Working Paper WP/08/283, December 2008.

[15] Kendall R - Zarzadzanie ryzykiem dla menadżerów. Liber, Warszawa, 2000.

[16] Klein R. W. - An overview of the insurance industry and its regulation. Centre for Risk Management and Insurance Research, Georgia State University, Draft June 12, 2008.

[17] Loos M.B.M. - Review of European consumer acquis. Centre for the Study of European Contract Law, Working Paper Series, No 2008/03, Amsterdam 2008.

[18] Neale F.R., Peterson P.P. - The effect of the Gramm-Leach-Bliley Act on the insurance industry. Florida State University, September 2003.

[19] Nieborak T. - Aspekty prawne funkcjonowania rynku finansowego Unii Europejskiej. Difin, Warszawa 2008.
[20] Potter S.W. - State regulation of life insurers: implications for economic efficiency and financial strength. University of Georgia, Athens, Georgia, May 30, 2007.

[21] Probhaker R. - And then there was one: conglomeration, internationalization and the formation of consolidated financial supervisors. BA Thesis, Harvard College, March 2009.

[22] Report on insurance laws, regulations and practices in IAIS member jurisdictions. IAIS, October 2005.

[23] Report on insurance laws, regulations and practices in IAIS member jurisdictions. IAIS, December 2007.

[24] Report on insurance laws, regulations and practices in IAIS member jurisdictions. IAIS, September 2008.

[25] Skipper H.D. Jr., Klein R.W. - Insurance regulation in the public interest; the path towards solvent, competitive markets. Centre for Risk Management and Insurance Research, Georgia State University, Atlanta, August 23, 1999.

[26] Surdej A. - Determinanty regulacji administracyjno-prawnych $w$ oddzialywaniu państwa na gospodarkę. Published by AE Kraków, Kraków, 2006.

[27] Sztaba S. - Kryzys finansowy 2007 w świetle ekonomicznej teorii regulacji [in] Nauki społeczne wobec kryzysu na rynkach finansowych. SGH, Warszawa 2008.

[28] Wallison P.J. - Convergence in financial services markets: likely effects on insurance regulation. American Enterprise Institute, July 9, 2008.

[29] Wallison P.J. - On principles-based regulation work in the United States. American Enterprise Institute for Public Policy research, June 8, 2007.

[30] Zingales L. - The costs and benefits of financial market regulation. European Corporate Governance Institute (EGGI), EGGI Working Paper Series in Law, Working Paper No 21/2004, April 2004. 